\title{
Molecular phylogeny of Lymantriinae (Lepidoptera, Noctuoidea, Erebidae) inferred from eight gene regions
}

\begin{tabular}{|r|l|}
\hline Journal: & Cladistics \\
\hline Manuscript ID: & CLA-14-08-0774 \\
\hline Manuscript Type: & Article \\
\hline Date Submitted by the Author: & 30 -Aug-2014 \\
\hline Complete List of Authors: & $\begin{array}{l}\text { Wang, Houshuai; Department of zoology; South China Agricultural } \\
\text { University, Department of Entomology } \\
\text { Wahlberg, Niklas; University of Turku, Department of Biology } \\
\text { Holloway, Jeremy; Natural History Museum, Department of Life Sciences } \\
\text { Bergsten, Johannes; Swedish Museum of Natural History, Department of } \\
\text { Zoology } \\
\text { Fan, Xiao-ling; South China Agricultural University, Department of } \\
\text { Entomology } \\
\text { Janzen, Daniel; University of Pennsylvania, Department of Biology } \\
\text { Hallwachs, Winnie; University of Pennsylvania, Department of Biology } \\
\text { Wen, Lijun; South China Agricultural University, Department of Entomology } \\
\text { Wang, Min; South China Agricultural University, Department of Entomology } \\
\text { Nylin, Soren; Stockholm University, Dept of Zoology }\end{array}$ \\
\hline Keywords: & \begin{tabular}{l} 
Classification < Taxonomy, Phylogeny, Entomology \\
\hline
\end{tabular} \\
\hline
\end{tabular}




\title{
Molecular phylogeny of Lymantriinae (Lepidoptera, Noctuoidea, Erebidae) inferred from eight gene regions
}

\author{
Houshuai Wang ${ }^{\mathrm{a}, \mathrm{b}}$, Niklas Wahlberg ${ }^{\mathrm{c}}$, Jeremy D. Holloway, Johannes \\ Bergsten $^{\mathrm{e}}$, Xiaoling Fan ${ }^{\mathrm{a}}$, Daniel H. Janzen ${ }^{\mathrm{f}}$, Winnie Hallwachs ${ }^{\mathrm{f}}$, Lijun \\ Wen $^{\mathrm{a}}$, Min Wang ${ }^{\mathrm{a}}{ }^{*}$ and Sören Nylin ${ }^{\mathrm{b}}$ \\ ${ }^{\text {a }}$ Department of Entomology, College of Natural Resources \& Environment, South China \\ Agricultural University, 510642 Guangzhou, China; ${ }^{\mathrm{b}}$ Department of Zoology, University of \\ Stockholm, SE-10691 Stockholm, Sweden; ${ }^{c}$ Department of Biology, Laboratory of Genetics, \\ University of Turku, 2014 Turku, Finland; d Department of Life Sciences, Natural History \\ Museum, Cromwell Road, SW7 5BD London, UK; ${ }^{\text {e }}$ Department of Zoology, Swedish Museum of \\ Natural History, SE-10405 Stockholm, Sweden; ${ }^{\mathrm{f}}$ Department of Biology, University of \\ Pennsylvania, Philadelphia, PA 19104, USA \\ * Corresponding author: Email address:minwang @scau.edu.cn
}

Running title: Molecular phylogeny of Lymantriinae 


\begin{abstract}
In order to understand the evolutionary history of Lymantriinae and test the present higher-level classification, we performed the first broad-scale molecular phylogenetic analysis of the subfamily, based on 154 exemplars representing all recognized tribes and drawn from all major biogeographic regions. We used two mitochondrial genes (cytochrome c oxidase subunit I and $16 S$ ribosomal RNA) and six nuclear genes (elongation factor-1 $\alpha$, carbamoylphosphate synthase domain protein, ribosomal protein S5, cytosolic malate dehydrogenase, glyceraldehyde-3-phosphate dehydrogenase and wingless). Data matrices (in total $5424 \mathrm{bp}$ ) were analysed by parsimony and model-based evolutionary methods (maximum likelihood and Bayesian inference). Based on the results of the analyses, we present a new phylogenetic classification for Lymantriinae composed of seven well-supported tribes, two of which are proposed here as new: Arctornithini, Leucomini, Lymantriini, Orgyiini, Nygmiini, Daplasini trib. nov. and Locharnini trib. nov..We discuss the internal structure of each of these tribes and address some of the more complex problems with the genus-level classification, particularly within Orgyiini and Nygmiini.
\end{abstract}


Table of contents:

Introduction

Materials and Methods

Taxon Sampling

DNA extraction, amplification and sequencing

Sequence alignment

Phylogenetic analyses

Results

Discussion

Tribe Arctornithini

Tribe Daplasini Holloway and Wang, trib. nov.

Tribe Locharnini Holloway and Wang, trib. nov.

Tribe Leucomini

Tribe Lymantriini

Tribe Orgyiini

Tribe Nygmiini

Biogeography

Acknowledgements

References 


\section{Introduction}

The Noctuoidea are the largest superfamily of the Lepidoptera, containing just over a quarter of the known species: 42407 according to Nieukerken et al. (2011). As such, they have presented a formidable challenge to obtaining a satisfactory, predictive, hierarchic classification that reflects evolutionary history (Kitching, 1984; Kitching and Rawlins, 1998; Fibiger and Lafontaine, 2005; Lafontaine and Fibiger, 2006; Zahiri et al., 2011). As for most groups of organisms, early classifications developed in the 18th and 19th centuries primarily from regional treatments with a small amount of serendipitous input from collections made on global voyages, but the very high diversity of the noctuoids tended to inhibit attainment of a global consensus from these regional efforts well into the cladistic era, particularly between those of the Old and New Worlds (reviewed by Franclemont and Todd, 1983; Kitching, 1984; Fibiger and Hacker, 1991; Poole, 1995; Fibiger and Lafontaine, 2005). While cladistic methodology provided a means to revise groups that had been based on plesiomorphic characters (e.g Noctuidae), the importance of taxon sampling soon became apparent (Hillis, 1996; Graybeal, 1998; Pollock et al., 2002; Zwickl and Hillis, 2002; Heath et al., 2008). Consequently, recent attempts based on multiple nuclear markers to reconstruct the evolutionary history of noctuoids and unify the classification have put strong emphasis on comprehensive taxon sampling in conjunction with targeting type-genera of family-level taxa (Mitchell et al., 2006; Regier et al., 2009; Zahiri et al., 2011, 2012). Despite these efforts, some large and economically important clades like the cosmopolitan tussock moths, variously treated at family or subfamily level (see 
below), were in these studies only partially included and are still lacking a higher-level classification based on a comprehensively sampled phylogenetic analysis. The present study aims to fill this gap motivated by the need to test and reconcile regional classifications and provide a phylogenetic framework for studies of host feeding evolution (foraging behaviour, host range), biogeographic history and diversification.

The subfamily Lymantriinae, commonly referred to as tussock moths, contains more than 2500 described species placed in approximately 360 genera, but the phylogenetic affinities within the group are very poorly understood. The subfamily is cosmopolitan in distribution with most species diversity in the Old World (Kitching and Rawlins, 1998). Species of the subfamily are predominantly arboreal defoliators in the larval stage and frequently polyphagous (Holloway, 1999). Some are major forest and agricultural pests such as Lymantria dispar Linnaeus (Gypsy Moth), L. monacha Linnaeus (Black Arches or Nun Moth), Orgyia antiqua Linnaeus (Vapourer or Rusty Tussock Moth), O. pseudotsugata McDunnough (Douglas-fir Tussock Moth), Leucoma salicis Linnaeus (White Satin Moth) and Arna pseudoconspersa Strand (Tea Tussock Moth) (Wallner, 1988; Chao, 2003; Pederson and Munson, 2006; Pogue and Schaefer, 2007; Ziemnicka, 2008; Uhlikova et al., 2011). The larvae of some species of the tribe Nygmiini like Euproctis chrysorrhoea Linnaeus (Brown-tail Moth) and Sphrageidus similis Fuessly (Yellow-tail Moth), possess urticating setae that can cause hazard to human health (Holloway et al., 1987; Common, 1990). The genus Toxoproctis Holloway is also notorious in this respect (Holloway, 1999). 154 species 
were listed as economically important by Zhang (1994), and over half the genera in which these are now placed are included in our analysis. This total represents about $10 \%$ of economically important Noctuoidea species, these representing a quarter of the total species of Lepidoptera listed by Zhang.

Lymantriinae are clearly noctuoid moths as they possess a metathoracic tympanum, which is considered a synapomorphy for the group. However, the taxonomic rank of this group has varied in different noctuoid classification systems. It was traditionally assigned family rank on the basis of morphological characters (Miller, 1991; Scoble, 1992; Kitching and Rawlins, 1998; Fibiger and Lafontaine, 2005), and was only recently downgraded to subfamily rank within the newly established family Erebidae, owing to the support of molecular data (Lafontaine and Fibiger, 2006; Zahiri et al., 2011, 2012). The larvae have a single and eversible mid-dorsal gland on each of the sixth and seventh abdominal segments; these glands are suggested to represent a apomorphy supporting the monophyly of Lymantriinae (Yela and Zahiri, 2011). Other distinctive features are: bipectinate antennae in the male with one to three spinules at the terminal of each branch; strongly reduced or absent proboscis; a prespiracular counter-tympanal hood; males with paired, pocket-like tymbal organs on the third abdominal sternite (Holloway, 1999).

Previous studies have identified two primary hypotheses regarding the sister-group and wider relationships of Lymantriinae (Speidel and Witt, 2011). One suggested that Arctiinae are the sister group of Lymantriinae (Mitchell et al., 2006; Regier et al., 2009), morphologically supported by synapomorphies such as a 
prespiracular counter-tympanal hood, general similarities of the male genitalia structures, and the terminal spinules of the bipectinate male antennae, though such spinules only occur on some arctiines. A sister-group relationship of Lymantriinae and Pantheinae is the alternative hypothesis (Kuznetzov and Stekolnikov, 2004; Stekolnikov and Speidel, 2009), proposed on the basis of the following characters: the presence of secondary setae in first instars; the well-developed pupal cremaster; the interapophysal position of the retractor muscles of the apophyses of the ninth segment; the absence of depressor muscles of the anal papillae in the adult female terminalia.

However, the first hypothesis is not clearly supported by recent molecular studies (Zahiri et al., 2011, 2012). These indicate, but without strong support, a sister-group relationship within the highly diverse Erebidae between Lymantriinae and a clade consisting of Pangraptinae, Aganainae, Herminiinae and Arctiinae. The second hypothesis is rejected by the clear placement of Pantheinae in a relatively basal position within a more restricted concept of Noctuidae (Zahiri et al., 2013).

Lymantriinae stand out amongst Erebidae in having non-feeding adults, in contrast to other groups of large physical size such as Erebinae and Calpinae where adult feeding is commonplace (Zaspel et al., 2012; Holloway et al., 2013). Holloway et al. (2013) noted parallels between these extremes in Erebidae and the alternative life strategies for tropical big moths proposed by Janzen (1984) with a focus on the Bombycoidea. Non-feeders tend to be short-lived, sexually dimorphic, with males searching for relatively static females calling with pheromone plumes; oviposition is in masses, with larvae aposematic or cryptic, often with urticating spines. Feeders 
tend to be long-lived, with sexual dimorphism weak at most, both sexes being active, often migratory; they oviposit singly, and the larvae are generally unspined and cryptic. Janzen also noted general larval host plant differences between the two categories, with non-feeders favouring hosts with foliage low in nutrients but rich in phenolics, and feeders favouring nutrient-rich foliage that is low in phenolics but may contain toxic alkaloids.

The classification within Lymantriinae remains quite fragmentary, and a comprehensive and global systematic study is still lacking. Ferguson (1978) treated Nearctic taxa of Lymantriidae (the previous concept as family-rank) as being within one single subfamily (Lymantriinae) that included two tribes, Lymantriini and Orgyiini, but felt that African and Indo-Australian taxa would probably represent additional subfamilies. Holloway (1999) followed Ferguson's concept of one subfamily, but recognized three additional tribes (Arctornithini, Leucomini and Nygmiini) based on Indo-Australian taxa. Benkhelil (1999) redefined Ferguson's Lymantriini and Orgyiini as two subfamilies mainly based on European taxa, with the genus Euproctis Hübner being transferred to Orgyiinae from Lymantriinae. More recently, Speidel and Witt (2011) supported Lymantriinae as a subfamily of Erebidae following the arrangement of Zahiri et al. (2011), and separated European Lymantriinae species into two tribes, Lymantriini and Orgyiini. These were further divided into five subtribes corresponding to five tribal groups of Holloway (1999): Lymantriini with Lymantriina, Arctornithina and Leucomina, and Orgyiini with Orgyiina and Nygmiina. However, Lafontaine and Schmidt (2013) commented that 
the concept of Orgyiini proposed by Speidel and Witt (2011) seemed not to be monophyletic. All of these studies are regional systematic overviews, and Neotropical taxa as well as the diverse African species have barely featured in the existing classification.

To date, little molecular information has been applied to elucidate the phylogenetic relationships within Lymantriinae. Mitchell et al. (2006) used two nuclear genes from a sample of four lymantriine genera, with the results indicating that Euproctis is more closely related to Lymantria Hübner than to Orgyia Ochsenheimer + Dasychira Hübner. Based on the five type genera representing separately the five lymantriine tribes of Holloway (1999) and the phylogenetic analysis of eight gene regions, Zahiri et al. $(2011,2012)$ proposed a phylogenetic hypothesis that Arctornithini are sister to the remaining four tribes, and that these are divided into two pairs: Orgyiini + Nygmiini and Lymantriini + Leucomini.

Here, we offer the first broad-scale molecular phylogenetic analyses of lymantriine moths using molecular data from eight gene regions to investigate the phylogenetic relationships and revise the existing classification within the subfamily.

\section{Materials and Methods \\ Taxon Sampling}

We selected 154 exemplars from 55 genera representing all the currently recognised lymantriine tribes and drawn from almost all biogeographic regions, together with 10 representatives of other Erebidae as outgroups. A list of taxa with the 
localities, voucher codes and GenBank accession numbers is provided in Tables S1. DNA extraction, amplification and sequencing

Total genomic DNA was extracted from one or two legs of adults, dried or freshly preserved in 96\% ethanol, using the TIANGENTM DNA extraction kit (Beijing, China) or the QIAGEN DNeasy tissue extraction kit (Hilden, Germany) following the manufacturer's instructions. For molecular markers, we selected cytochrome coxidase subunit I (COI) and, $16 S$ ribosomal RNA (16S rRNA) from the mitochondrial genome, and elongation factor-1 $\alpha(E F-1 \alpha)$, carbamoylphosphate synthase domain protein $(C A D)$, ribosomal protein S5 (RpS5), cytosolic malate dehydrogenase (MDH), glyceraldehyde-3-phosphate dehydrogenase (GAPDH) and wingless (WNT) from the nuclear genome. All these markers have previously been found to be highly informative in phylogenetic analyses of Lepidoptera (Wahlberg and Zimmermann, 2000; Wahlberg et al., 2009; Zahiri et al., 2011, 2012, 2013). DNA amplification and sequencing protocols follow (Wahlberg and Wheat, 2008) and (Wang et al., 2014).

\section{Sequence alignment}

The sequences obtained were edited and aligned using BioEdit version 7.2.0 (Hall, 1999) or MEGA version 5.0 (Tamura et al., 2011), except that the $16 S$ was aligned with the online version of MAFFT (http://mafft.cbrc.jp/alignment/server/). For the $16 S$ sequences, ambiguously aligned regions were identified and excluded using Gblock version 0.91b (Castresana, 2000; Talavera and Castresana, 2007), with parameters allowing for smaller final blocks, gap positions within the final blocks and less strict flanking positions. Neighbor-joining and maximum-likelihood trees were 
separately constructed for each gene to reduce errors in alignments and avoid the risk of confusion during sequencing.

\section{Phylogenetic analyses}

The data were analyzed using non-model-based (Maximum parsimony, MP) and model-based (Maximum likelihood, ML; and Bayesian Inference, BI) phylogenetic methods. For MP analysis, we performed New Technology heuristic searches (Goloboff, 1999) developed for large datasets using a "driven search" until minimum length was hit 10 times by means of a combination of Tree Fusion, Ratchet, Tree Drifting and Sectorial searches under default parameters in the program TNT version 1.1 (Goloboff et al., 2008). All characters were treated as unordered and equally weighted. Nodal support for each clade was estimated by Bremer support (Bremer, 1988; Bremer, 1994) using a script (Pena et al., 2006). For the model-based analyses, we used two different partitioning strategies: by gene regions (eight partitions) and by codon positions separated by genome source (see Miller et al., 2009; seven partitions: the first, second and third positions for nuclear genes, same for mitochondrial COI, and with ribosomal $16 S$ as a separate partition). GTR+G+I model was selected as the most appropriate model of sequence evolution for each gene and codon partition using the Akaike Information Criterion (AIC) implemented in MrModeltest2 (Nylander, 2004). However, MrModeltest only evaluates a subset of the 203 possible and reversible 4 by 4 substitution rate models. When evaluating all by using reversible-jump MCMC, commonly less complex models (3 or 4 rate parameters) than the GTR (6) are selected (Huelsenbeck et al, 2004). We therefore used the 
reversible-jump MCMC setting across model space in MrBayes 3.2 (Ronquist et al, 2011) but implemented the suggested gamma-distributed rate variation across sites (G) and the proportion of invariant sites (I). Based on Bayes factor tests on initial BI analyses, we decided to use the partitioning scheme by gene regions. Partitions were allowed to evolve at different rates and all other parameters of the model $(4 \times 4$ substitution rate matrix, state frequencies, among site rate variation and proportion of invariant sites) except branch length and topology were unlinked and estimated separately for each partition. The BI analysis was executed using MrBayes version 3.2.2 (Ronquist et al., 2012) on CIPRES Science Gateway (Miller et al., 2010), with the default parameters and four independent runs for 50000000 generations, each with one cold chain, sampled every 1000th generation, and three heated chains. Mixing, convergence and a suitable burn-in were assessed with the statistics provided by the program and with Tracer v. 1.6 (Rambaut et al., 2014), Post burn-in samples from the four runs were merged prior to the calculation of a majority-rule consensus tree. ML analysis was carried out with the web-server RAxML (Stamatakis et al., 2008) on CIPRES, using 1000 bootstrap replicates. Due to the debate about the correlation between parameters I and G (see Kelchner \& Thomas, 2007; Ren et al, 2005; Zahiri et al 2010) and whether G adequately models also invariant sites in the absence of I, we ran ML analysis under both $\mathrm{GTR}+\mathrm{G}$ and $\mathrm{GTR}+\mathrm{I}+\mathrm{G}$ for each partition. This merely affected a few poorly supported nodes and we report only on the result from the analysis using GTR+G. 
Results

The analyses of this study are based on the sequence data from two mitochondrial gene regions (670 bp of $C O I$ and 596 bp of $16 S$ ) and six nuclear gene regions (820 bp of $C A D, 1240$ bp of $E F-1 a, 691$ bp of $G A P D H, 407$ bp of $M D H, 600$ bp RPS5 and 400 bp of WNT). The final aligned data matrix contained 5424 nucleotide sites, of which 193 for the $16 S$ gene were excluded from subsequent analyses due to alignment ambiguities. Some genes failed to amplify for some taxa (Table S1).

The three phylogenetic analyses (MP, ML and BI) of the combined datasets for eight gene regions yield very similar topologies (Fig. 1, Fig. S1), and the monophyly of Lymantriinae is strongly supported by the model-based analyses $(\mathrm{BP}=99, \mathrm{PP}=1.00)$. All the topologies are characterized by seven major clades, although there are slight differences in the most parsimonious topological arrangement (Fig. S1). In the classification below we give the seven clades tribe status, two of which are proposed as new tribes. The tribes are Daplasini trib. nov., Arctornithini, Locharnini trib. nov., Leucomini, Lymantriini, Orgyiini and Nygmiini.

Daplasini are fully supported by our analyses as a monophyletic clade consisting of a single genus Daplasa Moore $(\mathrm{PP}=1.00 ; \mathrm{BP}=100 ; \mathrm{BS}=10)$. The Arctornithini clade is highly supported by the model-based analyses ( $\mathrm{PP}=1.00$; BP=94). Carriola Swinhoe, Topomesoides Strand and Sitvia Walker, with their type species sampled, render the genus Arctornis Germar paraphyletic with good support; the first two share its morphological features, but the status of Sitvia requires further 
study. MP analysis suggests that an African taxon Crorema ?jordani Collenette could also be included in Arctornithini, with only moderate support $(\mathrm{BS}=6)$, but the model-based analyses assign it to Lymantriini.

The monophyly of the Locharnini clade is well supported by the Bayesian analysis ( $\mathrm{PP}=0.96)$. Within the clade, the African genus Euproctoides Bethune-Baker, four Oriental genera Locharna Moore+Kuromondokuga Kishida+Ramadra Nye+Pida Walker and species currently misplaced in Numenes Walker and Dasychira come out as a strongly supported subclade $(\mathrm{PP}=1.00 ; \mathrm{BP}=100 ; \mathrm{BS}=9)$, in which Dasychira pilodes Collenette, Ramadra calligramma Walker and Numenes patrana Moore form a clade with Pida, and Numenes albofascia Leech and N. separata Leech are assigned to Kuromondokuga. The subclade appears as sister to a pairing of the African genus Ruanda Strand and the New World tropical genus Eloria Walker in the model-based analyses, but the latter two genera are not associated with the rest of Locharnini in the MP analysis.

The Leucomini clade is composed of Leucoma Hübner, Perina Walker and Ivela Swinhoe with high support in $\mathrm{ML}$ and $\mathrm{BI}$ analyses $(\mathrm{PP}=1.00 ; \mathrm{BP}=90)$. The genus Leucoma is found to be polyphyletic, as L. sericea Moore and L. chrysoscela Collenette form an assemblage together with Perina and Ivela. The parsimony consensus tree also includes an African genus Olapa Walker, but with very low support $(\mathrm{BS}=2)$.

Lymantriini are redefined to accommodate two African genera (Olapa, Crorema Walker), three New World ones (Sarsina Walker, Caviria Walker+Thagona Möschler), 
an Oriental clade (Imaus Moore+Cispia Walker+Dura Moore) and Lymantria on the basis of the model-based analyses. The Bayesian tree provides strong support for the monophyly of Lymantriini ( $\mathrm{PP}=1.00)$. The genus Parocneria Dyar is associated with Lymantria with high support $(\mathrm{PP}=1.00)$, but its position is unresolved with regard to Lymantria species.

The Oriental genus Ilema Moore and three African genera Aroa Walker, Hemerophanes Collenette and Mylantria Aurivillius constitute basal clades within Orgyiini, but the precise relationships lack good support. The remainder of the Orgyiini clade is strongly supported as a monophyletic group ( $\mathrm{PP}=1.00 ; \mathrm{BP}=72$; $\mathrm{BS}=16$ ). However, some current generic concepts within the group are polyphyletic. For example, the type species of Aroa, A. discalis Walker, is the species that is sister to Hemerophanes, while two Oriental exemplars, A. substrigosa Walker and an unidentified taxon, are grouped as sister to Pantana Walker with full support $(\mathrm{PP}=1.00 ; \mathrm{BP}=100 ; \mathrm{BS}=36)$ and are therefore not congeneric with the type. Olene inclusa Walker appears as sister to the members of Orgyia, but O. dudgeoni Swinhoe pairs with a representative of Telochurus Maes. The two Dasychira species are scattered across the distal clades of Orgyiini; a clade with four Orgyia species, including the type species $O$. antiqua, is strongly supported $(\mathrm{PP}=1.00 ; \mathrm{BP}=100$; $\mathrm{BS}=17)$.

Our results robustly recover the monophyly of the Nygmiini clade ( $\mathrm{PP}=1.00$; BP=99), but confirm that Euproctis and possibly Nygmia Hübner are polyphyletic groups. In Nygmiini, Albarracina Staudinger is the most basal taxon followed by the 
Bembina Walker+ Lacida Walker pair in both model-based trees, but this trio is broken up in the parsimony consensus tree. Somena Walker+Kidokuga Kishida and Orvasca Walker+Sphrageidus Maes form a strongly supported clade $(\mathrm{PP}=1.00$; $\mathrm{BP}=100 ; \mathrm{BS}=29)$. Arna Walker is a sister group to Artaxa Walker $(\mathrm{PP}=1.00 ; \mathrm{BP}=99$; BS=28), with Euproctis kanshireia Wileman, E. cryptosticta Collenette and E. sp3 included in the latter genus ( $\mathrm{PP}=0.97 ; \mathrm{BS}=6)$.

Resolution of the inter-tribal relationships within Lymantriinae remains limited in our analyses. Daplasini are found at the sister position to all other lymantriine lineages in the BI and MP trees, but branch off after Arctornithini in the ML tree. The model-based analyses indicated that Locharnini form the sister-group to a large clade formed by Leucomini+Lymantriini $\quad(\mathrm{PP}=1.00 ; \quad \mathrm{BP}=84) \quad$ and Orgyiini+Nygmiini( $\mathrm{PP}=0.99 ; \mathrm{BP}=66)$, but this lacks good support, while the MP analysis suggests that Locharnini branch off after Daplasini, followed by Orgyiini, with the remaining four tribes forming a polychotomy.

\section{Discussion}

The multi-gene phylogeny in this study, with extensive taxon sampling, recovers seven major lymantriine lineages that we define here as tribes, five of which are roughly concordant with the previous morphology-based concepts of five tribes recognized by Holloway (1999). With regard to the phylogenetic relationships among these five lineages, our results from the model-based analyses indicate that Arctornithini are a sister group to Orgyiini + Nygmiini together with Lymantriini + 
Leucomini, supporting the findings of Zahiri et al. (2010, 2012) which however dealt with higher taxonomic levels and sampled only a single species per tribe. The seven proposed tribes will be discussed in the following sections.

\section{Tribe Arctornithini}

Morphologically, the signum of the female genitalia is a broad, sparsely but uniformly scobinate plate, which has been thought to be an apomorphic character of Arctornithini (Holloway, 1999). Speidel and Witt (2011) downgraded this tribe to subtribe, placing it in their redefined Lymantriini based on larval characters. This taxonomic arrangement, however, is not supported by our molecular evidence, as Arctornithini appear in a more basal position in our phylogeny. Larval morphology in Arctornis has been found to be strikingly variable in Malaysian species in the form and distribution of hair-tufts (H. S. Barlow, pers. comm.).

Holloway (1999) originally proposed the tribe Arctornithini to accommodate two genera, Arctornis and Carriola. He mentioned that the two genera share many genital features. He also discussed the similarity of another unplaced genus, Sitvia, to Arctornis in some features of the genitalia and pupae. The Asian monotypic genus Topomesoides was previously assigned by Chao (2003) to his Orgyiinae concept, but the male genitalia of this genus illustrated by him show the definitive features of those of Arctornis. In this study, we found that Carriola, Topomesoides and Sitvia Walker (represented by their type species) fell within Arctornis with very strong support, and thus transfer them to that genus (syns. nov.), though the morphological justification for this in the case of Sitvia is weaker. 
Arctornis diaphora has undergone a series of taxonomic changes after it was described by Collenette (1934) in Leucoma and then transferred to Redoa Walker, a synonym of Arctornis established by Holloway (1999). This species was then placed in Carriola by Chao (2003), but with illustration of male genitalia that differ strikingly from those of Arctornis. Thus, A. diaphora, with distinct male genital characters and unusual discal spots on the hindwing similar to those of the forewing, has little in common with the species of Arctornis, and thus stands apart within Arctornithini. The basal phylogenetic position of this species in our analyses suggests that it needs further study, particularly with regard to the female.

The tribe has the highest species richness in the Oriental tropics, attenuating eastwards to New Guinea, and has been recorded feeding on a wide range of plant families. The genus Arctornis shows particular affinity for the Dipterocarpaceae at the larval stage, which may explain the conspicuous radiation of this group in Southeast Asian forests that are dominated by this plant family (Holloway, 1999; H. S. Barlow, unpublished).

Tribe Daplasini Holloway and Wang, trib. nov.

Type-genus: Daplasa Moore. Description: An areole is present in the forewing venation, with R5 branching from Rs more distally than R2. M3 and CuA1 separate in the hindwing. Male abdomen has tymbals. Uncus bifid, Aedeagus bulbous at base, with a single, needle-like cornutus.

Daplasini are proposed here as a new, currently monobasic (type genus Daplasa) tribe. Daplasa was previously included by Chao (2003) as a genus in his concept of 
Orgyiinae, on the basis of having an areole in the forewing. In our phylogeny, the Daplasini exemplars (two rather different species, including the type species, of Daplasa) formed a distinct group that fell into a basal position in the Lymantriinae clade. The aedeagus has a bulbous base and single, needle-like cornutus, which could offer an autapomorphy for this tribe. Also the uncus consists of two widely separated processes as in some Nygmiini, but the wing venation is plesiomorphic relative to that of nygmiines as described by Holloway (1999), who placed two related Bornean species, lyclene Swinhoe and albolyclene Holloway, under "Euproctis" in the tribe Nygmiini, but these now appear to be Daplasini and should be transferred to Daplasa, combs nov.. The venation features that set them apart from typical nygmiines are that R5 branches from Rs more distally than R2, rather than more basally, in the forewing, and $\mathrm{M} 3$ and $\mathrm{CuA} 1$ are separate in the hindwing, rather than stalked. The tribe is currently restricted to the Oriental Region and exhibits two distinct forewing pattern types: the typical one of irrorata Moore with diffuse, oblique banding; the more sharply marked blacklinea Chao type with a black postmedial and tornal streak, and a basal ring of red or yellow spots. The latter includes species such as variegata Moore and lyclene where the male has a dark suffusion to the forewing, and the female is white as in both sexes of blacklinea and albolyclene (postincisa Moore may be the female of variegata). The female genitalia of the latter group have a long ductus bursae with a prominent sclerotized collar distally, and a flat, somewhat ovate and marginally dentate signum in the corpus bursae. All members of the second group are here formally transferred to Daplasa, combs nov. 
Tribe Locharnini Holloway and Wang, trib. nov.

Type-genus: Locharna Moore. Description: Adults usually show obvious sexual dimorphism. Forewing venation has an areole from which R2 branches off near the apex, R5 somewhat connate or slightly stalked with R3+4. Rs stalked with M1 in the hindwing. Tymbals are present in the male abdomen. Male genitalia have apically sclerotized valves.

On the basis of our results, we erect the Locharnini as a new tribe, represented by two sublineages. One comprises two genera, Ruanda (Africa) and Eloria (Neotropics), and the other one encompasses the remainder of the sampled Locharnini. However, a sister relationship between the two sublineages is not well supported in our analyses. Therefore we tentatively incorporate both in this tribe until their phylogenetic structure is better resolved, but typify the tribe on Locharna in the larger and more cohesive sublineage. The tribe retains a more plesiomorphic condition, such as forewing venation with an areole. Species in the typical sublineage tend to have a short, robust uncus and relatively simple, apically sclerotized valves in the male genitalia. The type genus and two other Oriental genera, Pida and Kuromondokuga, are strikingly sexually dimorphic (Chao, 2003), and our results suggest that other taxa sequenced could be incorporated within one or the other of these genera, as follows:

Numenes was classified in Orgyiini by Holloway (1999), with the suggestion that placement of some Chinese species in this genus was problematic, as their male genitalia features were quite different from those of the type species N.siletti Walker. 
Our phylogeny indicates that Numenes is not a monophyletic group, even within Locharnini. This supports the morphological evidence, although no member of the typical group was available for sequencing. Here we transfer N. patrana to the genus Pida comb. nov., which then also includes Dasychira pilodes comb. nov. and Ramadra calligramma comb. nov., bringing Ramadra (= Mardara [praeocc.]) into synonymy with Pida, syn. nov. We transfer N. albofascia and N. separata into Kuromondokuga combs nov., a genus segregated by Kishida (2011) from Pida.

\section{Tribe Leucomini}

Members of the tribe Leucomini were morphologically defined by Holloway (1999) as sharing pronounced asymmetry in the male genitalia, though this feature is not seen in the type species of Leucoma. Leucoma currently consists of a group of many satiny white species with a reddish-orange tinge to the forelegs, and has been suggested to be paraphyletic (Holloway, 1999). This is confirmed by our molecular phylogeny, indicating that further revision of this genus is needed, possibly with revival of current synonyms such as Charala Moore (type species sericea) and Candidata Toxopeus (type species subargentea Felder). Leucoma ranges from the Palaearctic to Africa, New Guinea and Australia, with the highest species diversity in the Oriental tropics. Perina is an Oriental genus that displays extreme sexual dimorphism, the much smaller males being black with transparent areas in the wings; the larvae have only been recorded feeding on Ficus Röding (Moraceae). The Asian genus Ivela, now included in Leucomini, shares the definitive male genital characters with the other genera of the tribe. 


\section{Tribe Lymantriini}

The tribe Lymantriini was defined by Ferguson (1978) by the following features: adults lack an accessory cell (areole) in the forewing and the larvae do not have hair pencils or dense dorsal tufts on the first four abdominal segments. The tribe was subsequently redefined by Holloway (1999), with diagnostic features such as forewing facies with zig-zag or lunulate fasciation, a V-shaped discal spot and an orbicular spot. Speidel and Witt (2011) proposed a broader concept of this tribe that includes three subtribes (Lymantriina, Arctornithina and Leucomina), on the basis of larval characters that they considered to be apomorphic as follows: seta L1 replaced by a verruca in a postero-dorsal position from the spiracle; verrucas L2 and L3 approximate to each other on abdominal segments 1 to 6 . This concept is not supported by our results, so we follow Holloway's (1999) taxonomic treatment, but add two African genera (Olapa and Crorema), three New World genera (Caviria, Thagona and Sarsina) and the genus Cispia to Lymantriini. The tribe thus has a global distribution, but still with its greatest diversity in the Oriental Region; this picture may change as further African genera are sequenced.

The genus Lymantria is the most species rich genus, and there is sexual dimorphism in size and pattern. In our phylogeny, the internal structure within the genus accords quite closely with the morphological subgeneric phylogeny suggested by Schintlmeister (2004), except for the pairing of Parocneria with Lymantria. However, many of the subgenera remain to be sequenced. Sutrisno (2014) also noted extensive, but not complete, support for the subgenera of Schintlmeister (2004) in his 
analysis of COI gene data from a sample of just over 40 Lymantria species.

\section{Tribe Orgyiini}

Orgyiini are most clearly defined by the dorsal brushes on the first four larval abdominal segments (Holloway, 1999). The presence of an areole in the forewing was another diagnostic character suggested for this tribe by Ferguson (1978), but this feature is also found in Daplasini, Arctornithini and Locharnini, so is probably plesiomorphic.

The African sister genera Aroa and Hemerophanes and the genus Ilema, sharing the above larval features, are included as basal lineages in Orgyiini in our phylogeny, but lack good support for the precise positions. Further sampling is therefore needed to clarify their taxonomic placement.

Holloway (1982) revived the genus Calliteara Butler from synonymy with Dasychira and divided it into seven species groups. The monophyly of this genus is moderately supported by our analyses, with the African genus Griveaudyria Viette placed as sister to it. A high proportion of the species is montane, and all are robust with relatively narrow forewings. The larva is typically orgyiine, but with an additional, shorter, dorsal brush on the eighth segment, a feature also seen in Ilema and Cifuna Walker.

Our results provide strong support for the sister relationship of Laelia Stephens and Pantana, with Aroa substrigosa transferred here to the latter genus, comb. nov.. Both genera were discussed by Holloway (1999). Their larvae are considered to be specialists on Poaceae and Cyperaceae, and the adults are day-flying (Schaefer, 
1988). Psalis pennatula Fabricius (see below) also shows some preference for Poaceae.

The genus Dasychira as historically defined was thought to be a very complex group (Schaefer, 1988); this is further confirmed by our study, though Calliteara had already been excluded, as noted above. The type species, D. tephra Hübner, was considered by Ferguson (1978) to be part of an exclusively North American group and he suggested that Dasychira should be restricted to this group. It is placed in our study as sister to Cifuna. This pair is one of three subclades of a well supported distal clade of the Orgyiini that is sister to the African genus Neomardara Hering. Many generic names are represented in this clade, often by their type species, including Orgyia, leading Holloway (1999) to attempt to find an acceptable classification that excluded Dasychira and retained Orgyia, but in the process he broadened the concept of Olene Hübner to include the species dudgeoni. Our results indicate this to have been a mistake because dudgeoni is placed in the most basal subclade, but the more typical Olene inclusa is part of the third subclade that also includes Psalis Hübner, Teia Walker and a quartet of Orgyia species. The basal subclade includes a species thought to be a Telochurus and Dasychira glaucozona Collenette as well as dudgeoni. The oldest generic name available for this subclade is Pseudodura Strand, based on a current junior synonym of dudgeoni. More extensive sampling will be needed across this complex to resolve the generic classification satisfactorily.

\section{Tribe Nygmiini}

The tribe Nygmiini was described by Holloway (1999), comprising 16 genera. 
Most of these genera were segregated from the old concept of Euproctis. Kishida (2011) recognized another distinct genus, Kidokuga. Speidel and Witt (2011) transferred Albarracina to Nygmiini, a move supported by our analyses. The tribe is best defined by possession of a strong corethrogyne on an expanded seventh segment of the female. Holloway (1999) also noted characters that might be definitive as discussed earlier in relation to Daplasini; an areole is absent from most genera, another potential apomorphy. Our phylogeny with 13 genera sampled strongly supports the monophyly of the tribe, agreeing with the previous morphological classification.

In our results, the old broad concept of Euproctis remains extremely polyphyletic, and is in great need of revision, though the results do provide some reassurance that recent attempts to identify valid generic concepts within the Euproctis complex have some validity whilst at the same time emphasizing the scale of the task remaining.

The revival of the genus Bembina by Holloway (1999) is supported, but it is paired with Lacida; these genera do not appear to be close morphologically, with Bembina lacking tymbals and both genera having distinctive male genitalia.

The next large clade is well supported but mixes many species currently in Euproctis with representatives of Micromorphe Felder, Somena+Kidokuga and Orvasca+Sphrageidus, this last quartet sharing loss of vein M2 in the hindwing (Holloway, 1999).

Somena and Kidokuga form a well-supported lineage. The type species of both genera share a bicornute signum in bursa of the female, providing morphological 
support for the lineage, although their male genitalia structures show great differences (Kishida, 2011; Wang et al., 2011).

The lineage of Orvasca and Sphrageidus is also well supported. Orvasca has a major representation in Australia, referred to under Chionophasma Butler by Common (1990), and many of the smaller species in New Guinea and the south-west Pacific may also be referable to this genus (Holloway, 1999). Orvasca dolichocera Collenette in our analysis is an example of this from Vanuatu.

Also in this clade, the four Oriental species, E. singapura Swinhoe, E. pyraustis Meyrick, E. fumea Chao and E. seitzi Strand, share similar male genitalia structures, with the following diagnostic features: broadly bifid uncus, rather square valves and single cornutus in the aedeagus vesica (Schintlmeister, 1994; Chao, 2003). They form a well-supported clade $(\mathrm{PP}=1.00 ; \mathrm{BP}=100)$, which may represent a potential genus. Some allies such as E. wilemani Collenette and E. subfasciata Walker were noted by Holloway (1999).

All representatives of Nygmia sequenced except one are recovered in the next clade with moderate support. Probably many of the groups of larger species in Australasia will be found to belong here, as Holloway (1999) transferred several species to Nygmia from that region that typified some of the major species complexes.

The most distal clade in the Nygmiini, itself well supported, has three well-supported subclades. The first suggests a sister-relationship between Arna Walker and Artaxa. However, E. kanshireia, E. cryptosticta and E. sp3 are mixed in the genus Artaxa. 
The second includes a representative of Toxoproctis Holloway, counter to the suggestion by Holloway (1999) that this genus might be related to Sphrageidus. This subclade also includes species such as E. collenettei Chao and E. montis Leech that have similar male genitalia to Choerotricha biflava Holloway (Holloway, 1999; Chao, 2003). Three of the four the African Euproctis sequenced fall into this clade as a trio that forms a sister group to the species just mentioned. The fourth, tentatively identified as E. putris Hering, occupies a basal position in the next clade.

The third subclade includes the type species of Euproctis, chrysorrhoea, paired with the Palaearctic E. karghalica Wileman.

Nygmiini occur in the Old World with major higher level diversity in the Oriental tropics, but have yet to be identified in the New World. Most species appear to be polyphagous, although there are indications of some specialization on Loranthaceae by species groups in Nygmia (Holloway et al., 2001).

\section{Biogeography}

To conclude, we place these revised and globally based tribal concepts within Lymantriinae in a biogeographic context. All seven tribes are found in the Oriental Region, Daplasini uniquely so.

Arctornithini are highly diverse in the Oriental Region but extend into tropical Australasia and the Palaearctic. Leucomini are similar but relatively less diverse in the Oriental Region. The type genus and species, Leucoma salicis, extends to the Nearctic. The status of both tribes in Africa is unclear, but the genus Leucoma as 
currently constituted is represented by several species there.

Locharnini are more widespread, with significant pattern at a higher taxonomic level. The type lineage is restricted to the Oriental Region, but has a sister-genus in Africa. This group is in turn sister to a small but intriguing lineage of two genera: the African Ruanda and the Neotropical Eloria.

Lymantriini are the only other tribe to include Neotropical genera: Caviria, Sarsina and Thagona. Otherwise, this tribe is widespread and diverse in the Old World, more so in the tropics. One species, Lymantria dispar, occurs in the Nearctic as an introduction.

Nygmiini are essentially an Old World group with only the type species of Euproctis and Sphrageidus extending to the Nearctic. Again, the greatest diversity is Oriental, but the group is relatively rich in Australasia, and there appear to be distinct lineages in Africa.

Orgyiini have a similar distribution to Nygmiini but with a significant Nearctic representation consisting of the genus Dasychira and several species of Orgyia, one of which extends to Central America. Only Nygmiini and Orgyiini extend into the Pacific, but not further than Fiji and New Caledonia.

The lowest diversity at all levels appears to be in the New World, with little overlap between the Nearctic and the Neotropics. The genus Desmoloma Felder is of interest in the latter, as DNA barcoding results suggest that it is distinct from genera assigned in this analysis to the Locharnini and Lymantriini (Data from http://www.boldsystems.org). There are still a few unsequenced Oriental genera 
unplaced to tribe (Holloway, 1999), and there are many genera in Africa left to sequence; it is therefore possible that the synopsis above will see changes as these gaps are filled.

\section{Acknowledgements}

We thank the following persons who kindly loaned or provided specimens: Dr. Mamoru Owada (National Museum of Nature and Science, Tsukuba); Mr. Yasunori Kishida (Tokyo); Dr. Wolfgang Speidel (Witt Museum, München); Dr. Ulf Buchsbaum (Zoologische Staatssammlung München); Dr. Reza Zahiri, Dr. Evgeny V. Zakharov, Mr. Jayme Sones (University of Guelph, Guelph); Mr. Henry Barlow (Malaysia); Dr. Markku Pellinen (Finland); Dr. Scott Miller (Smithsonian National Museum of Natural History, Washington, DC). The first author would like to thank Dr. Wolfgang Speidel (Witt Museum, München), Dr. Dieter Stüning (Zoological Research Museum Alexander Koenig, Bonn) and Dr. Wolfram Mey (Museum für Naturkunde, Berlin), Mr. Christian Kutzscher (Senckenberg Deutsches Entomologisches Institut, Müncheberg), Dr. Alberto Zilli (Natural History Museum, London) for their kind help during his examination for the Lymantriinae types. This work was supported by Oversea Study Program of Guangzhou Elite Project (Sui jiaoke [2012] 59), by the Swedish Research Council (2011-5636) to SN and by Academy of Finland to NW.

\section{References}


Benkhelil, M. L. 1999. Redefinition of the two main lineages of the family Lymantriidae Lepidoptera, Geometridae. Nouvelle Revue d'Entomologie 16, 137-146.

Bremer, K. 1988. The limits of Amino-Acid Sequence data in Angiosperm phylogenetic reconstruction. Evolution 42, 795-803.

Bremer, K. 1994. Branch support and Tree Stability. Cladistics 10, 295-304.

Castresana, J. 2000. Selection of conserved blocks from multiple alignments for their use in phylogenetic analysis. Mol. Biol. Evol. 17, 540-552.

Chao, Z. L. 2003. Lepidoptera Lymantriidae. Fauna Sinica, Insecta 30. Science Press, Beijing.

Collenette, C. L. 1934. The Lymantriidae of Kwang-Tung (S.E. China). Novit. Zool. $39,137-150$.

Common, I. F. B. 1990. Moths of Australia. E.J. Brill and Melbourne University Press, Melbourne.

Ferguson, D. C. 1978. The Moths of America North of Mexico. Noctuoidea, Lymantriidae. Vol 22-2. E. W. Classey Limited and The Wedge Entomological Research Foundation, London.

Fibiger, M., Hacker, H. 1991. Systematic list of the Noctuidae of Europe. Esperiana 2, $1-109$.

Fibiger, M., Lafontaine, J. D. 2005. A review of the higher classification of the Noctuoidea (Lepidoptera) with special reference to the Holarctic fauna. Esperiana $11,7-92$. 
Franclemont, J. G., Todd, E. L. 1983. Noctuidae. In: Hodges, R. W. et al. (Ed.) Check List of the Lepidoptera of America North of Mexico. E. W. Classey Limited and the Wedge Entomological Research Foundation, London, pp. 120-159.

Goloboff, P. A. 1999. Analyzing large data sets in reasonable times: Solutions for composite optima. Cladistics 15, 415-428.

Goloboff, P. A., Farris, J. S., Nixon, K. C. 2008. TNT, a free program for phylogenetic analysis. Cladistics 24, 774-786.

Graybeal, A. 1998. Is it better to add taxa or characters to a difficult phylogenetic problem? Syst. Biol. 47, 9-17.

Hall, T. A. 1999. BioEdit: a user-friendly biological sequence alignment editor and analysis program for Windows 95/98/NT. Nucleic Acids Symposium Series 41, 95-98.

Heath, T. A., Hedtke, S. M., Hillis, D. M. 2008. Taxon sampling and the accuracy of phylogenetic analyses. J. Syst. Evol. 46, 239-257.

Hillis, D. M. 1996. Inferring complex phylogenies. Nature 383, 130-131.

Holloway, J. D. 1982. Taxonomic appendix. In: Barlow, H. S. An introduction to the Moths of South East Asia. the author, Kuala Lumpur.

Holloway, J. D. 1999. The moths of Borneo (part 5): Family Lymantriidae. Malay. Nat. J. 53, 1-188.

Holloway, J. D., Barlow, H. S., Hok, K. L., Chey, C. V. 2013. Sweet or Savoury? Adult feeding preferences of Lepidopetera attracted to banana and prawn baits in the Oriental Tropics. Raffles B Zool. Suppl. No. 29, 71-90. 
Holloway, J. D., Bradley, J. D., Carter, D. J. 1987. Lepidoptera. In: Betts, C. R. (Ed.) CIE Guides to Insects of Importance to Man. CAB International, Wallingford, pp. $1-262$.

Holloway, J. D., Kibby, G., Peggie, D., Carter, D. J., Miller, S. E. 2001. The families of Malesian Moths and Butterflies. Fauna Malesiana Handbook 3. E. J. Brill, Leiden.

Huelsenbeck, J. P., Larget, B., Alfaro, M. E. 2004. Bayesian phylogenetic model selection using reversible jump Markov chain Monte Carlo. Mol. Biol. Evol. 21, $1123-1133$.

Janzen, D. H. 1984. Two ways to be a tropical big moth: Santa Rosa saturniids and sphingids. Oxford Surveys in Evolutionary Biology 1, 85-140.

Kelchner, S. A., Thomas, M. A. 2007. Model use in phylogenetics: nine key questions. Trends Ecol. Evol. 22, 87-94.

Kishida, Y. 2011. Descriptions of new species and new subspecies of Japanese Macrolepidoptera (2), with descriptions of 2 new genera. Tinea 21, 129-135.

Kitching, I. J. 1984. An historical review of the higher classification of the Noctuidae (Lepidoptera). Bull. Br. Mus. (Nat. Hist.). Entomol. 49, 153-234.

Kitching, I. J., Rawlins, J. 1998. The Noctuoidea. In: Kristensen, N. P. (Ed.) Handbook of Zoology, Lepidoptera, Moths and Butterflies. Vol. 1. W. de Gruyter, Berlin, pp. 355-402.

Kuznetzov, V. I., Stekolnikov, A. A. 2004. Musculature of female terminal segments and tis significance in systematics of the superfamilies Notodontoidea and 
Noctuoidea (Lepidoptera: Noctuiformes). Entomol. Obozr. 83, 286-307.

Lafontaine, J. D., Fibiger, M. 2006. Revised higher classification of the Noctuoidea (Lepidoptera). Can. Entomol. 138, 610-635.

Lafontaine, J. D., Schmidt, B. C. 2013. Comments on differences in classification of the superfamily Noctuoidea (Insecta, Lepidoptera) between Eurasia and North America. ZooKeys, 209-217.

Miller, J. S. 1991. Cladistics and classification of the Notodontidae (Lepidoptera, Noctuoidea) based on larval and adult morphology. Bull. Am. Mus. Nat. Hist. 204, $1-230$.

Miller K. B., Bergsten J., Whiting, M. F. 2009. Phylogeny and classification of the tribe Hydaticini (Coleoptera, Dytiscidae, Dytiscinae): Partition choice for Bayesian analysis with multiple nuclear and mitochondrial protein-coding genes. Zool. Scr. 38, 591-615.

Miller, M. A., Pfeiffer, W., Schwartz, T. 2010. Creating the CIPRES Science Gateway for inference of large phylogenetic trees. Proc Gateway Comput Environ Workshop (GCE), pp. 1-8.

Mitchell, A., Mitter, C., Regier, J. C. 2006. Systematics and evolution of the cutworm moths (Lepidoptera : Noctuidae): evidence from two protein-coding nuclear genes. Syst. Entomol. 31, 21-46.

Nieukerken, E. J. van, Kaila, L., Kitching, I. J., Kristensen, N. P., Lees, D. C., Minet, J., Mitter, C., Mutanen, M., Regier, J. C., Simonsen, T. J., Wahlberg, N., Yen, S.-H., Zahiri, R., Adamski, D., Baixeras, J., Bartsch, D., Bengtsson, B. Å., Brown, 
J. W., Bucheli, S. R., Davis, D. R., DePrins, J., De Prins, W., Epstein, M. E., Gentili-Poole, P., Gielis, C., Hättenschwiler, P., Hausmann, A., Holloway, J. D., Kallies, A., Karsholt, O., Kawahara, A., Koster, S. J. C., Kozlov, M., Lafontaine, J. D., Lamas, G., Landry, J.-F., Lee, S., Nuss, M., Penz, C., Rota, J., Schmidt, B. C., Schintlmeister, A., Sohn, J. C., Solis, M. A., Tarmann, G. M., Warren, A. D., Weller, S., Yakovlev, R., Zolotuhin, V., Zwick, A. 2011. Order Lepidoptera Linnaeus, 1758. In: Zhang, Z.-Q. (Ed.). Animal biodiversity: An outline of higher-level classification and survey of taxonomic richness. Zootaxa 3148, 212-221.

Nylander, J. A. A. 2004. MrModelTest v2. Program distributed by the author. Evolutionary Biology Centre. Uppsala University, Uppsala

Pederson, L., Munson, S. 2006. Management Guide for Gypsy Moth. Forest Health Protection and State Forestry Organizations, pp. 1-7.

Pena, C., Wahlberg, N., Weingartner, E., Kodandaramaiah, U., Nylin, S., Freitas, A. V. L., Brower, A. V. Z. 2006. Higher level phylogeny of Satyrinae butterflies (Lepidoptera : Nymphalidae) based on DNA sequence data. Mol. Phylogenet. Evol. 40, 29-49.

Pogue, M. G., Schaefer, P. W. 2007. A review of selected species of Lymantria Hübner (1819) (Lepidoptera: Noctuidae: Lymantriinae) from subtropical and temperate regions of Asia, including the descriptions of three new species, some potentially invasive to North America. Forest Health Technology Enterprise Team, Colorado. Pollock, D. D., Zwickl, D. J., Mcguire, J. A., Hillis, D. M. 2002. Increased taxon 
sampling is advantageous for phylogenetic infer- ence. Syst. Biol. 51, 664-671.

Poole, R. W. 1995. Noctuoidea: Noctuidae (part), Cuculliinae, Stiriinae, Psaphidinae (part). In: Dominick, R. B. e. a. (Ed.) The Moths of America North of Mexico. Fascicle 26. 1, pp. 1-249.

Rambaut, A., Suchard, M. A., Xie, D., Drummond, A. J. 2014. Tracer v1.6. Available from http://beast.bio.ed.ac.uk/Tracer.

Regier, J. C., Zwick, A., Cummings, M. P., Kawahara, A. Y., Cho, S., Weller, S., Roe, A., Baixeras, J., Brown, J. W., Parr, C., Davis, D. R., Epstein, M., Hallwachs, W., Hausmann, A., Janzen, D. H., Kitching, I. J., Solis, M. A., Yen, S. H., Bazinet, A. L., Mitter, C. 2009. Toward reconstructing the evolution of advanced moths and butterflies (Lepidoptera: Ditrysia): an initial molecular study. BMC Evol. Biol. 9, 21.

Ren, F. R., Tanaka, H., Yang, Z. H. 2005. An empirical examination of the utility of codon-substitution models in phylogeny reconstruction. Syst. Biol. 54, 808-818.

Ronquist, F., Teslenko, M., van der Mark, P., Ayres, D. L., Darling, A., Hohna, S., Larget, B., Liu, L., Suchard, M. A., Huelsenbeck, J. P. 2012. MrBayes 3.2: Efficient Bayesian Phylogenetic Inference and Model Choice Across a Large Model Space. Syst. Biol. 61, 539-542.

Schaefer, P. W. 1988. Diversity in form, function, behavior, and ecology: An overview of the Lymantriidae (Lepidoptera) of the world. In: Wallner, W. E., McManus, K. A. (Eds.), Proceedings, Lymantriidae: a comparison of features of New and Old World tussock moths. USDA Forest Service, Gen Tech Rpt NE-123, Broomall, 
PA, pp. 1-19.

Schintlmeister, A. 1994. An annotated and illustrated check-list of the Lymantriidae of Sumatra with descriptions of new species (Lepidoptera, Lymantriidae). Heteroc. Sumatr. 7, 113-180.

Schintlmeister, A. 2004. The taxonomy of the genus Lymantria Hübner, [1819] (Lepidoptera: Lymantriidae). Quadrifina 7, 1-248.

Scoble, M. J. 1992. The Lepidoptera: Form, Function and Diversity. Oxford University Press, Oxford.

Speidel, W., Witt, T. J. 2011. Subfamilia Lymantriinae Hampson, [1893]. Noctuidae Europaeae, Vol. 13. Entomological Press, Sorø, pp. 45-79.

Stamatakis, A., Hoover, P., Rougemont, J. 2008. A Rapid Bootstrap Algorithm for the RAxML Web Servers. Syst. Biol. 57, 758-771.

Stekolnikov, A. A., Speidel, W. 2009. Taxonomische Stellung der Gattungen Panthea, Trichosea und Diloba (Lepidoptera, Noctuoidea, Pantheidae" und Noctuidae) unter Berücksichtigung der stammesgeschichtlichen Beziehungen zu den Lymantriidae. Entomofauna 30, 61-104.

Sutrisno, H. 2014. Molecular phylogeny of Indonesian Lymantria Tussock Moths (Lepidoptera: Erebidae) based on CO I gene sequences. Journal of Species Research 3, 7-16.

Talavera, G., Castresana, J. 2007. Improvement of phylogenies after removing divergent and ambiguously aligned blocks from protein sequence alignments. Syst. Biol. 56, 564-577. 
Tamura, K., Peterson, D., Peterson, N., Stecher, G., Nei, M., Kumar, S. 2011. MEGA5: Molecular Evolutionary Genetics Analysis Using Maximum Likelihood, Evolutionary Distance, and Maximum Parsimony Methods. Mol. Biol. Evol. 28, 2731-2739.

Uhlikova, H., Nakladal, O., Jakubcova, P., Turcani, M. 2011. Outbreaks of the Num Moth (Lymantria monacha) and Historical risk regions in the Czech Republic. Sumar. List 135, 477-486.

Wahlberg, N., Leneveu, J., Kodandaramaiah, U., Pena, C., Nylin, S., Freitas, A. V. L., Brower, A. V. Z. 2009. Nymphalid butterflies diversify following near demise at the Cretaceous/Tertiary boundary. Proc. R. Soc. B-Biol. Sci. 276, 4295-4302.

Wahlberg, N., Wheat, C. W. 2008. Genomic outposts serve the phylogenomic pioneers: Designing novel nuclear markers for genomic DNA extractions of lepidoptera. Syst. Biol. 57, 231-242.

Wahlberg, N., Zimmermann, M. 2000. Pattern of phylogenetic relationships among members of the tribe Melitaeini (Lepidoptera : Nymphalidae) inferred from mitochondrial DNA sequences. Cladistics 16, 347-363.

Wallner, W. E. 1988. Overview of Pest Lymantriidae of North America. In: Wallner, W. E., McManus, K. A. (Eds.), Proceedings, Lymantriidae: a comparison of features of New and Old World tussock moths. USDA Forest Service, Gen Tech Rpt NE-123, Broomall, PA, pp. 65-79.

Wang, H. S., Fan, X. L., Owada, M., Wang, M., Nylin, S. 2014. Phylogeny, Systematics and Biogeography of the Genus Panolis (Lepidoptera: Noctuidae) 
Based on Morphological and Molecular Evidence. Plos One 9, 13.

Wang, H. S., Wang, M., Fan, X. L. 2011. Notes on the tribe Nygmiini (Lepidoptera: Erebidae: Lymantriinae) from Nanling National Nature Reserve, with description of a new species. Zootaxa 2887, 57-68.

Yela, J. L., Zahiri, R. 2011. Phylogenetic overview of Noctuidae sensu lato. In: Witt, T. J., Ronkay, L. (Eds.), Noctuidae Europaeae, vol. 13. Entomological press, Sorø, pp. 17-22.

Zahiri, R., Holloway, J. D., Kitching, I. J., Lafontaine, J. D., Mutanen, M., Wahlberg, N. 2012. Molecular phylogenetics of Erebidae (Lepidoptera, Noctuoidea). Syst. Entomol. 37, 102-124.

Zahiri, R., Kitching, I. J., Lafontaine, J. D., Mutanen, M., Kaila, L., Holloway, J. D., Wahlberg, N. 2011. A new molecular phylogeny offers hope for a stable family level classification of the Noctuoidea (Lepidoptera). Zool. Scr. 40, 158-173.

Zahiri, R., Lafontaine, D., Schmidt, C., Holloway, J. D., Kitching, I. J., Mutanen, M., Wahlberg, N. 2013. Relationships among the basal lineages of Noctuidae (Lepidoptera, Noctuoidea) based on eight gene regions. Zool. Scr. 42, 488-507.

Zaspel, J. M., Zahiri, R., Hoy, M. A., Janzen, D., Weller, S. J., Wahlberg, N. 2012. A molecular phylogenetic analysis of the vampire moths and their fruit-piercing relatives (Lepidoptera: Erebidae: Calpinae). Mol. Phylogenet. Evol. 65, 786-791.

Zhang, B. C. 1994. Index of Economically Important Lepidoptera. CAB International, Wallingford.

Ziemnicka, J. 2008. Outbreaks and Natural Viral Epizootics of the Satin Moth 


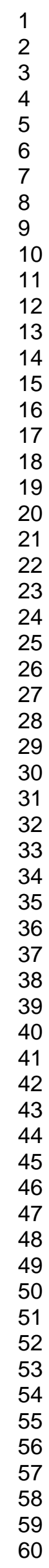

Leucoma Salicis L. (Lepidoptera: Lymantriidae). J. Plant Protect. Res. 48, 23-38.

Zwickl, D. J., Hillis, D. M. 2002. Increased taxon sampling greatly reduces phylogenetic error. Syst. Biol. 51, 588-598. 
Figure

Fig. 1. Majority rule consensus tree from the BI analysis of the full dataset. Posterior probabilities from $\mathrm{BI}$ analysis and bootstrap support values from the $\mathrm{ML}$ analysis are indicated at the nodes as PP/BP.

\section{Supplementary Information}

Fig. S1. Strict consensus of 4 equally parsimonious trees from the combined dataset of all eight genes (length 29824 CI 0.145 RI 0.542). Numbers given above branches are Bremer support values.

Table. S1. List of taxa with voucher codes and Genbank accession numbers (TS refers to Type species). 


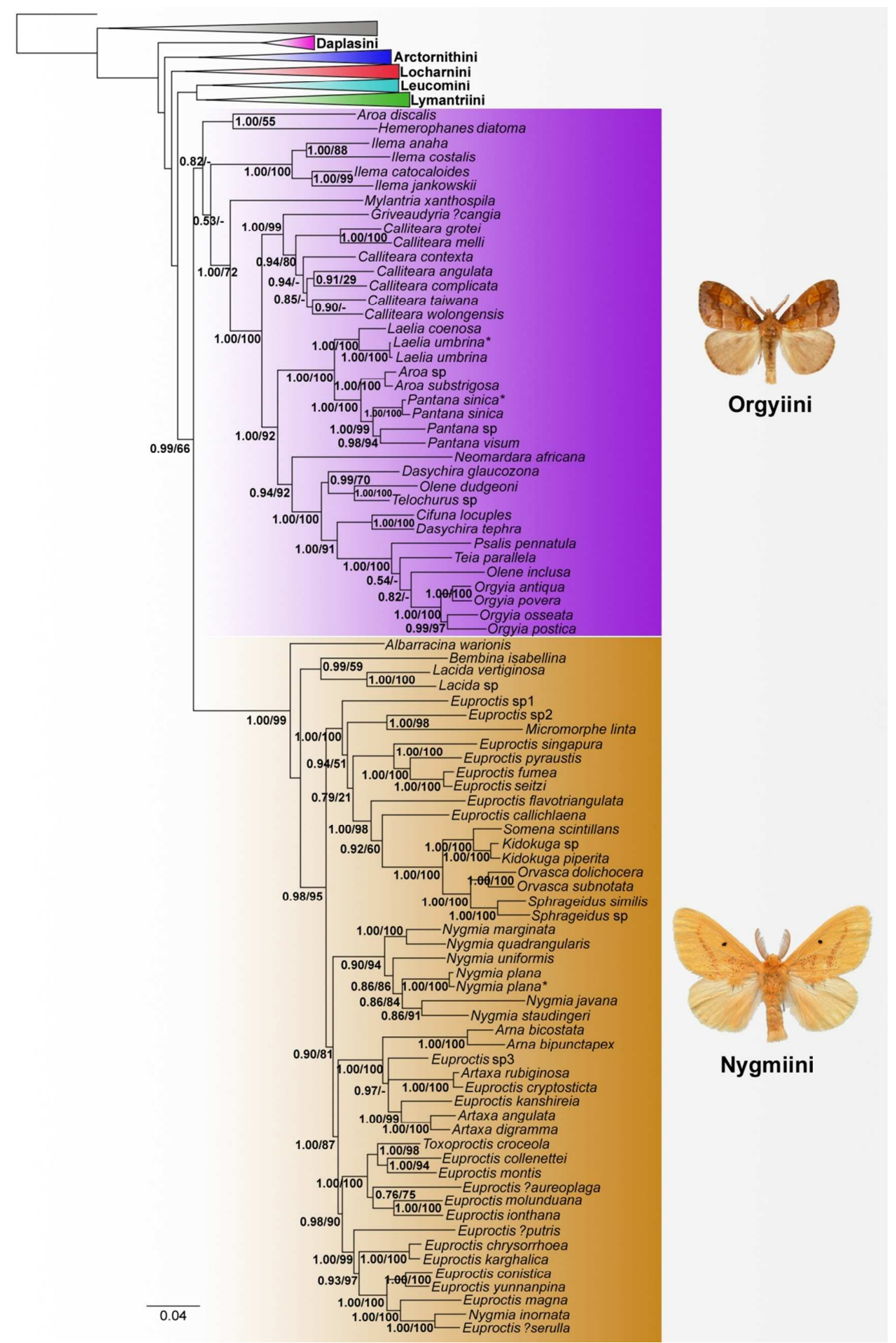

Fig.1. Majority rule consensus tree from the BI analysis of the full dataset. Posterior probabilities from $\mathrm{BI}$ analysis and bootstrap support values from the $\mathrm{ML}$ analysis are indicated at the nodes as PP/BP. 


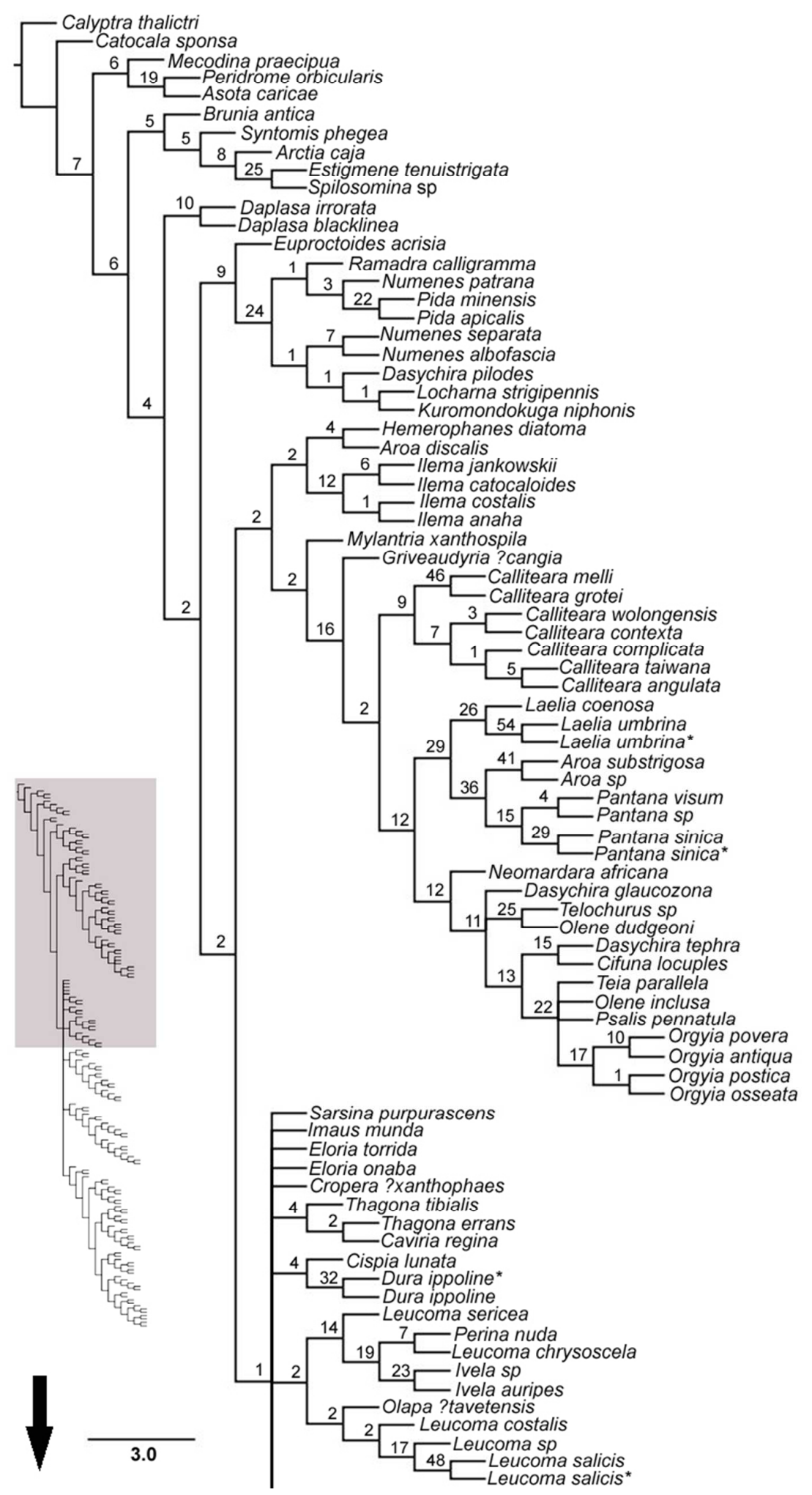



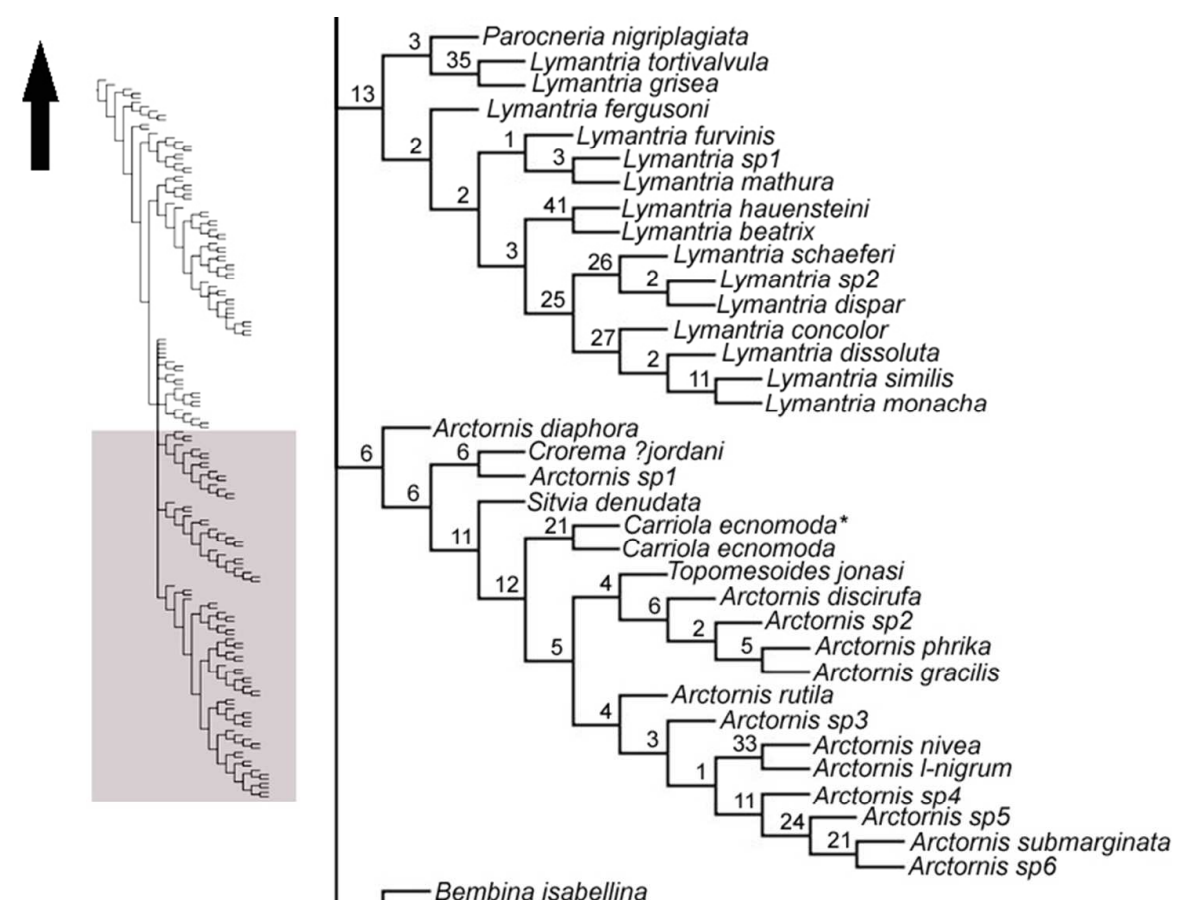

Bembina isabellina

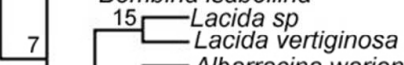

Albarracina warionis

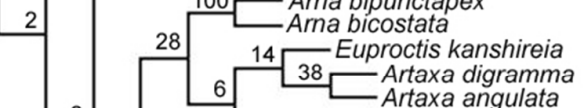

2 Euproctis sp3 6

Artaxa rubiginosa

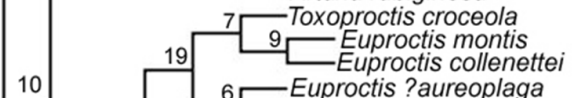

10

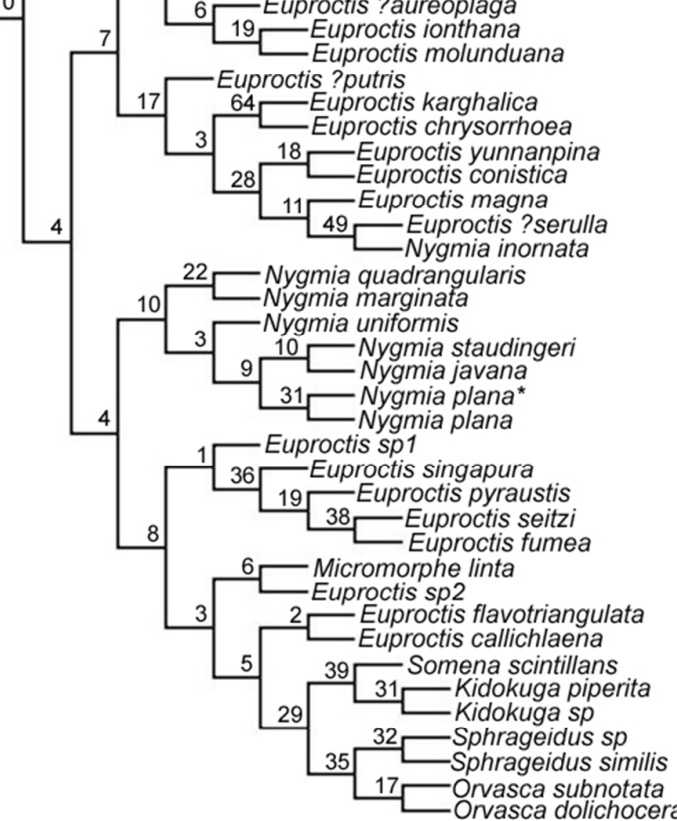

Fig. S1. Strict consensus of 4 equally parsimonious trees from the combined dataset of all eight genes (length 29824 CI 0.145 RI 0.542). Numbers given above branches are Bremer support values. 
Table S1. List of taxa with voucher codes and Genbank accession numbers (TS refers to Type species).

\begin{tabular}{|c|c|c|c|c|c|c|c|c|c|c|c|c|c|c|}
\hline Subfamily & Tribe & genus & species & Locality & Voucher codes & $\begin{array}{l}\text { Type } \\
\text { Status }\end{array}$ & COI & $16 \mathrm{~S}$ & EF1-a & wingless & RPS5 & $\mathrm{MDH}$ & GAPDH & CAD \\
\hline Calpinae & Calpini & Calyptra & thalictri & Finland & MM00963 & TS & & & & & & & & \\
\hline Erebinae & Catocalini & Catocala & sponsa & Finland & MM04358 & & & & & & & & & \\
\hline Aganainae & & Mecodina & praecipua & China & RZ268 & & & & & & & & & \\
\hline Aganainae & Aganaini & Peridrome & orbicularis & Malaysia & $\mathrm{RZ280}$ & TS & & & & & & & & \\
\hline Aganainae & Aganaini & Asota & caricae & Thailand & MM00145 & TS & & & & & & & & \\
\hline Arctiinae & Lithosiini & Brunia & antica & China & $\mathrm{RZ28}$ & TS & & & & & & & & \\
\hline Arctiinae & Arctiini & Arctia & caja & Finland & MM03713 & TS & & & & & & & & \\
\hline Arctiinae & Syntomini & Syntomis & phegea & Hungary & RZ8 & TS & & & & & & & & \\
\hline Arctiinae & Spilosomini & Estigmene & tenuistrigata & Zambia & $\mathrm{T} 1$ & & & & & & & & & \\
\hline Arctiinae & Spilosomini & Spilosomina & $\mathrm{sp}$ & Ghana & M5 & & & & & & & & & \\
\hline Lymantriinae & Arctornithini & Carriola & ecnomoda & Malaysia & H379 & TS & & & & & & & & \\
\hline Lymantriinae & Arctornithini & Carriola & ecnomoda* & & NSGJZ006 & TS & & & & & & & & \\
\hline Lymantriinae & Arctornithini & Arctornis & diaphora & China & $\mathrm{H} 209$ & & & & & & & & & \\
\hline Lymantriinae & Arctornithini & Arctornis & sp1 & China & $\mathrm{H} 148$ & & & & & & & & & \\
\hline Lymantriinae & Arctornithini & Arctornis & discirufa & Brunei & S93 & & & & & & & & & \\
\hline Lymantriinae & Arctornithini & Arctornis & sp2 & Thailand & H392 & & & & & & & & & \\
\hline Lymantriinae & Arctornithini & Arctornis & phrika & Brunei & $\mathrm{S} 88$ & & & & & & & & & \\
\hline Lymantriinae & Arctornithini & Arctornis & gracilis & China & $\mathrm{H} 220$ & & & & & & & & & \\
\hline Lymantriinae & Arctornithini & Arctornis & rutila & Brunei & S89 & & & & & & & & & \\
\hline Lymantriinae & Arctornithini & Arctornis & 1-nigrum & China & $\mathrm{H} 164$ & TS & & & & & & & & \\
\hline Lymantriinae & Arctornithini & Arctornis & nivea & China & A99 & & & & & & & & & \\
\hline Lymantriinae & Arctornithini & Arctornis & sp3 & Thailand & H391 & & & & & & & & & \\
\hline
\end{tabular}




\begin{tabular}{|c|c|c|c|c|c|c|}
\hline \multirow{2}{*}{ Lymantriinae } & Arctornithini & Arctornis & \multicolumn{2}{|l|}{ sp4 } & \multicolumn{2}{|l|}{ NSGJZO04 } \\
\hline & Arctornithini & Arctornis & sp5 & Japan & \multicolumn{2}{|l|}{ RZ89 } \\
\hline Lymantriinae & Arctornithini & Arctornis & submarginata & China & \multicolumn{2}{|l|}{ H372 } \\
\hline Lymantriinae & Arctornithini & Arctornis & sp6 & China & \multicolumn{2}{|l|}{ H149 } \\
\hline Lymantriinae & Arctornithini & Sitvia & denudata & Malaysia & H382 & TS \\
\hline Lymantriinae & Arctornithini & Topomesoides & jonasi & China & H348 & TS \\
\hline Lymantriinae & Daplasini & Daplasa & irrorata & China & H229 & TS \\
\hline Lymantriinae & Daplasini & Daplasa & blacklinea & China & H166 & \\
\hline Lymantriinae & Locharnini & Ruanda & aetheria & S. Sudan & M11 & TS \\
\hline Lymantriinae & Locharnini & Eloria & onaba & Costa Rica & \multicolumn{2}{|l|}{ 10-SRNP-72499 } \\
\hline Lymantriinae & Locharnini & Eloria & torrida & Costa Rica & \multicolumn{2}{|l|}{ 11-SRNP-35118 } \\
\hline Lymantriinae & Locharnini & Euproctoides & acrisia & Zambia & \multicolumn{2}{|l|}{ M1 } \\
\hline Lymantriinae & Locharnini & Locharna & strigipennis & China & H159 & TS \\
\hline Lymantriinae & Locharnini & Kuromondokuga & niphonis & China & H167 & TS \\
\hline Lymantriinae & Locharnini & Numenes & albofascia & China & H190 & \\
\hline Lymantriinae & Locharnini & Numenes & separata & China & H347 & \\
\hline Lymantriinae & Locharnini & Numenes & patrana & China & $\mathrm{H} 3$ & \\
\hline Lymantriinae & Locharnini & Ramadra & calligramma & China & $\mathrm{H} 4$ & TS \\
\hline Lymantriinae & Locharnini & Pida & minensis & China & H114 & \\
\hline Lymantriinae & Locharnini & Pida & apicalis & China & H2O5 & TS \\
\hline Lymantriinae & Locharnini & Dasychira & pilodes & China & H370 & \\
\hline Lymantriinae & Leucomini & Leucoma & costalis & China & H373 & \\
\hline Lymantriinae & Leucomini & Leucoma & $\mathrm{sp}$ & China & H377 & \\
\hline Lymantriinae & Leucomini & Leucoma & salicis & China & H351 & TS \\
\hline Lymantriinae & Leucomini & Leucoma & salicis* & Finland & MM06740 & TS \\
\hline Lymantriinae & Leucomini & Leucoma & sericea & China & $\mathrm{H} 120$ & \\
\hline
\end{tabular}




\begin{tabular}{|c|c|c|c|c|c|c|}
\hline Lymantriinae & Leucomini & Leucoma & chrysoscela & Vietnam & $\mathrm{S} 83$ & \\
\hline Lymantriinae & Leucomini & Ivela & $\mathrm{sp}$ & China & $\mathrm{H} 340$ & \\
\hline Lymantriinae & Leucomini & Ivela & auripes & China & $\mathrm{H} 49$ & TS \\
\hline Lymantriinae & Leucomini & Perina & nuda & China & H181 & TS \\
\hline Lymantriinae & Lymantriini & Olapa & ? tavetensis & Zimbabwe & M6 & \\
\hline Lymantriinae & Lymantriini & Caviria & regina & Costa Rica & 12-SRNP-41748 & \\
\hline Lymantriinae & Lymantriini & Thagona & tibialis & Costa Rica & 07-SRNP-58990 & \\
\hline Lymantriinae & Lymantriini & Thagona & errans & Costa Rica & 11-SRNP-3924 & \\
\hline Lymantriinae & Lymantriini & Imaus & munda & Laos & HSO1 & \\
\hline Lymantriinae & Lymantriini & Cispia & lunata & China & H125 & \\
\hline Lymantriinae & Lymantriini & Dura & ippoline & China & H121 & TS \\
\hline Lymantriinae & Lymantriini & Dura & ippoline* & Laos & HS6 & TS \\
\hline Lymantriinae & Lymantriini & Crorema & ? jordani & S. Sudan & M10 & \\
\hline Lymantriinae & Lymantriini & Sarsina & purpurascens & Costa Rica & 11-SRNP-72098 & \\
\hline Lymantriinae & Lymantriini & Parocneria & nigriplagiata & China & $\mathrm{H} 60$ & \\
\hline Lymantriinae & Lymantriini & Lymantria & furvinis & China & $\mathrm{H} 62$ & \\
\hline Lymantriinae & Lymantriini & Lymantria & fergusoni & China & H124 & \\
\hline Lymantriinae & Lymantriini & Lymantria & grisea & China & $\mathrm{H} 6$ & \\
\hline Lymantriinae & Lymantriini & Lymantria & tortivalvula & China & H269 & \\
\hline Lymantriinae & Lymantriini & Lymantria & sp1 & Madagascar & SM01 & \\
\hline Lymantriinae & Lymantriini & Lymantria & mathura & China & $\mathrm{H} 122$ & \\
\hline Lymantriinae & Lymantriini & Lymantria & beatrix & Thailand & $\mathrm{H} 401$ & \\
\hline Lymantriinae & Lymantriini & Lymantria & hauensteini & China & H361 & \\
\hline Lymantriinae & Lymantriini & Lymantria & sp2 & Madagascar & S01 & \\
\hline Lymantriinae & Lymantriini & Lymantria & dispar & Turkey & S04 & TS \\
\hline Lymantriinae & Lymantriini & Lymantria & schaeferi & China & H317 & \\
\hline
\end{tabular}




\begin{tabular}{|c|c|c|c|c|c|c|}
\hline Lymantriinae & Lymantriini & Lymantria & concolor & China & \multicolumn{2}{|l|}{ H37 } \\
\hline Lymantriinae & Lymantriini & Lymantria & dissoluta & China & \multicolumn{2}{|l|}{ H127 } \\
\hline Lymantriinae & Lymantriini & Lymantria & similis & China & \multicolumn{2}{|l|}{ H58 } \\
\hline Lymantriinae & Lymantriini & Lymantria & monacha & Finland & \multicolumn{2}{|l|}{ MM01048 } \\
\hline Lymantriinae & Orgyiini & Hemerophanes & diatoma & Zambia & \multicolumn{2}{|l|}{ M7 } \\
\hline Lymantriinae & Orgyiini & Aroa & discalis & Zambia & M2 & TS \\
\hline Lymantriinae & Orgyiini & Mylantria & xanthospila & Uganda & T8 & TS \\
\hline Lymantriinae & Orgyiini & Griveaudyria & ?cangia & Zambia & \multicolumn{2}{|l|}{ M4 } \\
\hline Lymantriinae & Orgyiini & Calliteara & taiwana & China & \multicolumn{2}{|l|}{ H218 } \\
\hline Lymantriinae & Orgyiini & Calliteara & complicata & China & \multicolumn{2}{|l|}{ H291 } \\
\hline Lymantriinae & Orgyiini & Calliteara & angulata & China & \multicolumn{2}{|l|}{ H112 } \\
\hline Lymantriinae & Orgyiini & Calliteara & wolongensis & China & \multicolumn{2}{|l|}{$\mathrm{H} 248$} \\
\hline Lymantriinae & Orgyiini & Calliteara & contexta & China & \multicolumn{2}{|l|}{ H161 } \\
\hline Lymantriinae & Orgyiini & Calliteara & grotei & China & \multicolumn{2}{|l|}{ H135 } \\
\hline Lymantriinae & Orgyiini & Calliteara & melli & China & \multicolumn{2}{|l|}{ H29 } \\
\hline Lymantriinae & Orgyiini & Laelia & coenosa & China & \multirow{2}{*}{\multicolumn{2}{|c|}{$\begin{array}{l}\mathrm{H} 14 \\
\mathrm{H} 20\end{array}$}} \\
\hline Lymantriinae & Orgyiini & Laelia & umbrina & China & & \\
\hline Lymantriinae & Orgyiini & Laelia & umbrina* & China & \multicolumn{2}{|l|}{ H111 } \\
\hline Lymantriinae & Orgyiini & Aroa & $\mathrm{sp}$ & China & \multicolumn{2}{|l|}{ S25 } \\
\hline Lymantriinae & Orgyiini & Aroa & substrigosa & China & \multicolumn{2}{|l|}{ H134 } \\
\hline Lymantriinae & Orgyiini & Pantana & sinica & China & \multicolumn{2}{|l|}{ H34 } \\
\hline Lymantriinae & Orgyiini & Pantana & sinica* & China & \multicolumn{2}{|l|}{ H162 } \\
\hline Lymantriinae & Orgyiini & Pantana & visum & Thailand & \multicolumn{2}{|l|}{ H390 } \\
\hline Lymantriinae & Orgyiini & Pantana & $\mathrm{sp}$ & Vietnam & \multicolumn{2}{|l|}{ S11 } \\
\hline Lymantriinae & Orgyiini & Neomardara & africana & Zambia & $\mathrm{T} 2$ & TS \\
\hline Lymantriinae & Orgyiini & Dasychira & tephra & USA & BIOUG01420-B05 & TS \\
\hline
\end{tabular}




\begin{tabular}{|c|c|c|c|c|c|c|}
\hline Lymantriinae & Orgyiini & Dasychira & glaucozona & China & $\mathrm{H} 25$ & \\
\hline Lymantriinae & Orgyiini & Psalis & pennatula & Thailand & H385 & \\
\hline Lymantriinae & Orgyiini & Telochurus & $\mathrm{sp}$ & China & H52 & \\
\hline Lymantriinae & Orgyiini & Olene & dudgeoni & China & H63 & \\
\hline Lymantriinae & Orgyiini & Olene & inclusa & China & H131 & \\
\hline Lymantriinae & Orgyiini & Cifuna & locuples & China & $\mathrm{H} 47$ & TS \\
\hline Lymantriinae & Orgyiini & Teia & parallela & China & H349 & \\
\hline Lymantriinae & Orgyiini & Orgyia & osseata & Brunei & S28 & \\
\hline Lymantriinae & Orgyiini & Orgyia & postica & Vietnam & S22 & \\
\hline Lymantriinae & Orgyiini & Orgyia & antiqua & Finland & RZ130 & \\
\hline Lymantriinae & Orgyiini & Orgyia & povera & Costa Rica & 12-SRNP-13137 & \\
\hline Lymantriinae & Orgyiini & Ilema & jankowskii & China & $\mathrm{H} 26$ & \\
\hline Lymantriinae & Orgyiini & Ilema & catocaloides & China & $\mathrm{H} 160$ & \\
\hline Lymantriinae & Orgyiini & Ilema & costalis & China & $\mathrm{H} 200$ & TS \\
\hline Lymantriinae & Orgyiini & Ilema & anaha & Vietnam & S07 & \\
\hline Lymantriinae & Nygmiini & Albarracina & warionis & Morocco & M8 & \\
\hline Lymantriinae & Nygmiini & Bembina & isabellina & Malaysia & H383 & \\
\hline Lymantriinae & Nygmiini & Lacida & vertiginosa & Laos & S51 & \\
\hline Lymantriinae & Nygmiini & Lacida & $\mathrm{sp}$ & Thailand & H389 & \\
\hline Lymantriinae & Nygmiini & Micromorphe & linta & Malaysia & H381 & TS \\
\hline Lymantriinae & Nygmiini & Somena & scintillans & China & H141 & TS \\
\hline Lymantriinae & Nygmiini & Kidokuga & piperita & China & H367 & TS \\
\hline Lymantriinae & Nygmiini & Kidokuga & $\mathrm{sp}$ & China & H368 & \\
\hline Lymantriinae & Nygmiini & Sphrageidus & $\mathrm{sp}$ & Madagascar & S34 & \\
\hline Lymantriinae & Nygmiini & Sphrageidus & similis & China & $\mathrm{H} 46$ & TS \\
\hline Lymantriinae & Nygmiini & Orvasca & subnotata & China & $\mathrm{H} 110$ & TS \\
\hline
\end{tabular}




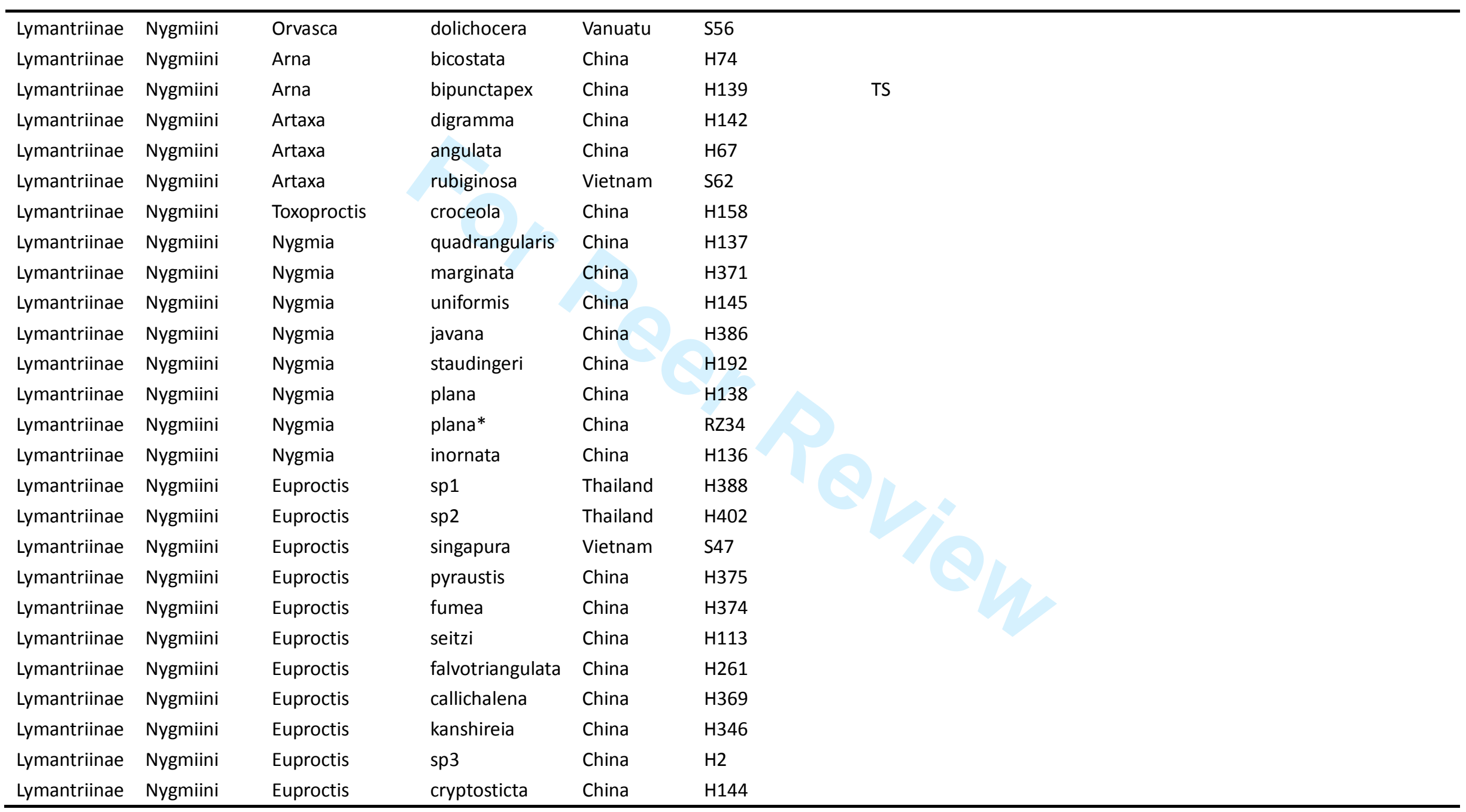




\section{Page 51 of 51}

Cladistics

\begin{tabular}{|c|c|c|c|c|c|c|}
\hline Lymantriinae & Nygmiini & Euproctis & ? aureoplaga & Madagascar & S50 & \\
\hline Lymantriinae & Nygmiini & Euproctis & molunduana & Uganda & M3 & \\
\hline Lymantriinae & Nygmiini & Euproctis & ? ionthada & Uganda & M9 & \\
\hline Lymantriinae & Nygmiini & Euproctis & montis & China & H350 & \\
\hline Lymantriinae & Nygmiini & Euproctis & collenettei & China & H353 & \\
\hline Lymantriinae & Nygmiini & Euproctis & ? putris & Zambia & $\mathrm{T} 10$ & \\
\hline Lymantriinae & Nygmiini & Euproctis & karghalica & China & H352 & \\
\hline Lymantriinae & Nygmiini & Euproctis & chrysorrhoea & Sweden & H380 & TS \\
\hline Lymantriinae & Nygmiini & Euproctis & conistica & China & $\mathrm{H} 76$ & \\
\hline Lymantriinae & Nygmiini & Euproctis & yunnanpina & China & A102 & \\
\hline Lymantriinae & Nygmiini & Euproctis & magna & China & HS31 & \\
\hline Lymantriinae & Nygmiini & Euproctis & ?serulla & China & $\mathrm{H} 23$ & \\
\hline
\end{tabular}

